\title{
Recent Developments in Metal Oxide Gas Sensors for Breath Analysis
}

\author{
Ji-Wook Yoon and Jong-Heun Lee ${ }^{\dagger}$ \\ Korea University, Seoul 02473, Korea \\ 산화물 반도체를 이용한 최신 호기센서 기술 동향 \\ 윤지욱, 이종흔 ${ }^{\dagger}$ \\ 고려대학교 신소재공학과
}

(Received February 22, 2019; Accepted March 5, 2019)

\begin{abstract}
s
Breath analysis is rapidly evolving as a non-invasive disease recognition and diagnosis method. Metal oxide gas sensors are one of the most ideal platforms for realizing portable, hand-held breath analysis devices in the near future. This paper reviewed the recent developments in metal oxide gas sensors detecting exhaled biomarker gases such as nitric oxides, acetone, ammonia, hydrogen sulfide, and hydrocarbons. Emphasis was placed on strategies to tailor sensing materials/films capable of highly selective and sensitive detection of biomarker gases with negligible cross-response to ethanol, the major interfering breath gas. Specific examples were given to highlight the validity of the strategies, which include optimization of sensing temperature, doping additives, utilizing acid-base interaction, loading catalysts, and controlling gas reforming reaction. In addition, we briefly discussed the design and optimization method of gas sensor arrays for implementing the simultaneous assessment of multiple diseases. Breath analysis using high-performance metal oxide gas sensors/arrays will open new roads for point-of-care diagnosis of diseases such as asthma, diabetes, kidney dysfunction, halitosis, and lung cancer.
\end{abstract}

Keywords: Metal oxide; Gas sensor; Sensor array; Breath analysis; Disease diagnosis

\section{1. 서론}

1970년대 Pauling이 GC-MS (Gas Chromatography
-Mass Spectroscopy)를 이용하여 사람의 날숨에 약 250 여종의 휘발성 유기화합물(Volatile Organic Compounds, VOC)이 포함되어 있음을 발표한 이후1), 
인체 호기 분석을 통한 질병 진단에 대한 연구가 지속적 으로 증가하고 있다. 이는 기존의 검진 방법이 일반적으 로 고가의 장비를 필요로 하거나, 혈액이나 조직 채취가 요구되어 환자의 불편을 가중시키는 반면, 호기 분석은 저비용, 비침습적 진단으로 검사에 대한 환자의 거부감을 낮추고 진단 비용을 크게 감소시킬 수 있기 때문이다. 또 한 호기 분석은 질병의 발생으로 인한 체내 신진대사 활 동의 변화를 즉각적으로 모니터링 할 수 있어 질병의 조 기 진단에 유리하며, 따라서 환자의 회복 가능성을 높이 고 치료비용을 크게 감소시킬 수 있다.

호기 가스의 주성분은 질소 $(75 \%)$, 산소 $(13 \%)$, 습기(6 $\%)$, 이산화탄소 $(5 \%)$ 이지만, 이 밖에도 많게는 수 $\mathrm{ppm}$ (part per million)에서 적게는 수 ppt (part per trillion) 수준의 다양한 $\mathrm{VOC}$ 가 존재하며, 이 중 일부가 질병과 밀 접한 연관이 있는 것으로 알려져 있다2). 대표적으로 산화 질소, 아세톤, 암모니아, 황화수소가 각각 천식, 당뇨, 신 장병, 구취 환자에게서 더 높은 농도로 배출된다고 알려 져 있으며 ${ }^{3)}$, 폐암 환자의 경우 탄화수소 계 $\mathrm{VOC}$ 의 농도 가 정상인에 비해 증가하거나 감소한다는 보고가 있담. 따라서, 이와 같은 미량의 생체 지표 가스(biomarker gases)들을 정확하게 분석하면 여러 질병들을 간편한 방 법으로 조기에 진단할 수 있다.

현재까지 호기 분석을 위한 장비로는 GC-MS가 널리 활용되어왔으며1), 최근에는 $\mathrm{GC}$ 의 단점을 보완한 PTR (Proton Transfer Reaction)-MS, SIFT (Selected Ion Flow Tube)-MS 등이 임상에 활용되고 있다2). 위와 같 은 장비들은 미량의 $\mathrm{VOC}$ 에 대한 정밀한 분석이 가능하 지만, 부피가 크고 고가이므로 일반인이 질병 모니터링 이나 질병 조기 진단을 위한 목적으로 활용하는 것은 거 의 불가능하다. 이에 최근 크기가 작고 가격이 저렴한 산 화물 반도체형 가스센서를 스마트폰과 같은 휴대용 전자 기기에 통합하여 개개인이 병원 방문 없이도 직접 본인 의 날숨을 분석 및 모니터링 할 수 있도록 하는 시스템의 개발이 진행 중에 있다. 그러나 산화물 반도체형 가스센 서는 수백여 종의 가스들이 혼재하는 사람의 호기에서 극미량의 생체 지표 가스만을 선택적으로 검출하는데 어 려움이 있고, 특히 사람의 날숨에 상대적으로 고농도(0
- $1663 \mathrm{ppb}^{4)}$ )로 존재하는 에탄올에 높은 가스감도를 나 타내는 문제로 인해 정밀한 호기 분석에 한계를 보이고 있다.

이러한 문제점을 극복하기 위해 현재 다수의 센서로 어 레이를 구성하고, 이들의 감응 신호를 패턴인식 방법으로 해석하는 전자 코(E-nose) 기술이 연구되고 있다. 전자 코 기술은 호기와 같은 복잡한 혼합 가스를 분석하는데 장점이 있지만, 선택성이 부족한 센서들로 어레이를 구성 할 경우 그 장점을 제대로 활용할 수 없고, 때로는 단일 센서에 비해 오히려 저하된 가스 검지 성능을 나타내기도 한다. 따라서 전자 코의 잠재력을 극대화하기 위해서는 선택성이 우수한 센서들로 어레이를 구성해야 하며, 이를 위해 특정 생체 지표 가스에 고감도, 고선택성을 나타내 는 단일 센서의 개발이 선행되어야 한다. 본고는 호기 분 석을 통한 질병 진단이 가능하다고 알려진 천식, 당뇨, 신 장병, 구취 및 폐암 진단에 활용될 수 있는 생체 지표 가 스(산화질소, 아세톤, 암모니아, 황화수소, 탄화수소)들 을 에탄올 대비 고감도, 고선택적으로 검지 할 수 있는 산 화물 반도체형 가스센서 설계 방안 및 전략들을 소개하 고, 호기 분석 용 전자 코 구현을 위한 고성능 단일 센서 개발의 필요성을 강조했다.

\section{2. 본론}

\section{1 산화물 반도체형 가스센서의 감응원리}

산화물 반도체는 $100 \sim 500{ }^{\circ} \mathrm{C}$ 의 고온에 노출되면 공 기 중의 산소를 표면에 흡착하며, 흡착된 산소는 반도체 표면으로부터 전자를 빼앗아 음전하를 띄게 된다 $\left(\mathrm{O}_{2}^{-}\right.$, $\left.\mathrm{O}^{-}, \mathrm{O}^{2-}\right)$. 이는 전자가 주 전하이동자인 $\mathrm{n}$ 형 산화물 반도 체 $\left(\mathrm{SnO}_{2}\right)$ 표면에 전자공핍층(electron depletion layer) 을 형성시키며(Fig. 1a1), 정공이 주 전하이동자인 p형 산 화물 반도체 $\left(\mathrm{Co}_{3} \mathrm{O}_{4}\right)$ 의 표면에는 정공과잉층(hole accumulation layer)을 형성시킨다(Fig. 1b1). 환원성 가스인 일산화탄소 $(\mathrm{CO})$, 아세톤, 암모니아 등이 유입되 면 반도체 표면에 흡착되어 있던 산소와 반응하여 가스가 산화되고, 이 과정에서 산소에 빼앗겼던 전자가 다시 반 도체의 전자공핍층 또는 정공과잉층으로 주입되기 때문 


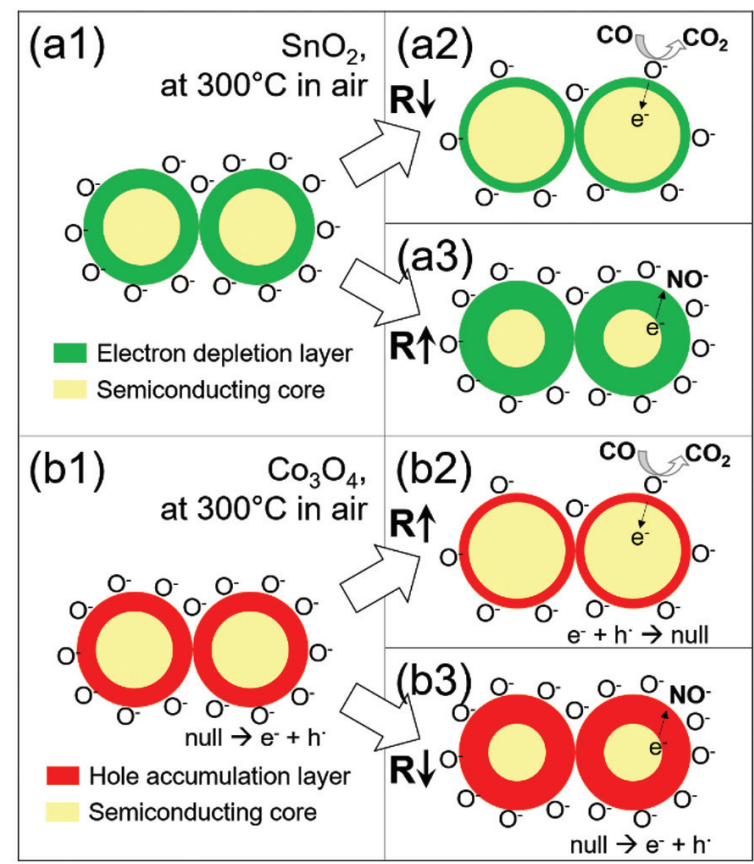

Fig. 1. (a) $\mathrm{SnO}_{2}$ (n형) (b) $\mathrm{Co}_{3} \mathrm{O}_{4}$ (p형) 가스센서의 가스 감응 기구

에 센서의 저항이 감소하거나(n형, Fig. 1a2) 증가하게 (p형, Fig. 1b2) 된다. 반대로, 산화질소(NO)와 같은 산 화성 가스는 반도체 표면에 직접 흡착하여 반도체 표면의
전자를 더 빼앗아 전자공핍층이나 정공과잉층이 더욱 확 장되므로, 가스와의 반응으로 저항이 증가하거나(n형, Fig. 1a3) 감소하게(p형, Fig. 1b3) 된다. 이러한 전기저 항의 증감을 가스감도 $\left(\mathrm{n}\right.$ 형; $\mathrm{R}_{\mathrm{a}} / \mathrm{R}_{\mathrm{g}}$ : 공기 중 저항/가스 중 저항, $\mathrm{p}$ 형; $\mathrm{R}_{\mathrm{g}} / \mathrm{R}_{\mathrm{a}}$ 로 정의하며, 일반적으로 가스감도는 가스의 농도에 비례하므로 가스의 존재 유무 및 농도를 확인할 수 있다.

위와 같은 간단한 가스 감응 기구는 미량의 가스를 저 비용으로 검출하고 센서를 소형 전자기기에 쉽게 통합하 는데 큰 이점으로 작용하지만, 여러 가지 환원성 가스 또 는 산화성 가스가 함께 존재할 경우 특정 가스만을 선택 적으로 검출하는 것이 어려워지는 문제가 있다. 특히, 대 부분의 산화물 반도체형 가스센서가 반응성이 우수한 에 탄올에 대해 높은 가스감도를 나타내므로 혼합 가스에 에 탄올이 섞여 있을 경우 그 외의 가스에 대한 정밀한 분석 이 매우 어려워진다. 이에 에탄올 대비 특정 가스에 대한 선택성 확보를 위해 센서 구동 온도 최적화5), 산화물 첨 가제 도핑5-7), 가스와 감응 소재 간 산-염기 반응 유도 8-10), 귀금속 또는 산화물 촉매 도포11-13) 및 가스 감응막 내 가스 리포밍 조절14,15) 등의 방법이 활용되고 있다.
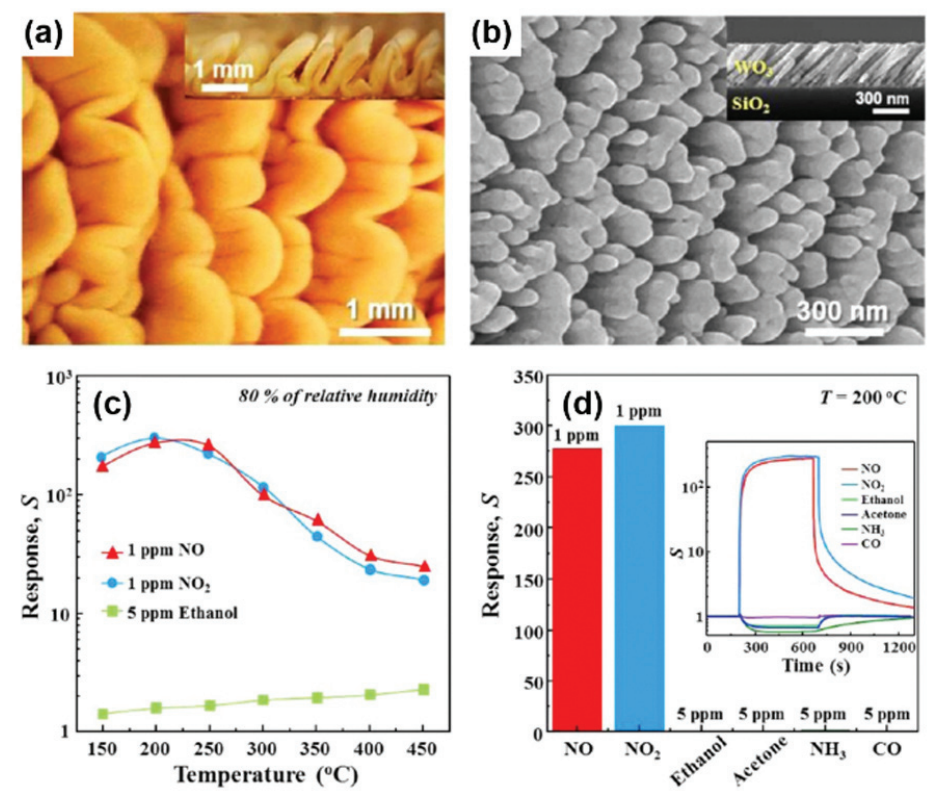

Fig. 2. (a, b) 스침각 증착법으로 제작한 $\mathrm{WO}_{3}$ villi-like nanofinger (VLNF); (c, d) VLNF의 가스 감응 특성 19 ) 


\section{2 질병 진단 용 산화물 반도체형 가스센서}

\subsection{1 천식 진단 용 산화질소 센서}

천식은 호흡 곤란을 일으키는 염증성 기도 폐쇄 질환으 로 환자의 경우 기도염증에서 촉진된 산화질소의 과도한 합성으로 정상인에 비해 높은 농도의 산화질소가 호기에 서 검출된다 ${ }^{16)}$. 일반적으로 알려진 천식 환자의 호기 산 화질소 농도는 $30 \mathrm{ppb}$ 이상으로 정상인( 16 ppb)에 비 해 2 배 가까이 높다 17 . 그러나 사람의 호기에 일반적으로 존재하는 에탄올 $\left(0-1663 \mathrm{ppb}^{4}\right)$ 에 비해 그 농도가 매우 낮기 때문에 정확한 진단을 위해서는 고감도 및 에탄올 대비 극히 우수한 산화질소 선택성이 요구된다.

산화질소는 대표적인 산화성 가스로 반도체 표면에 직 접 흡착하여 센서의 저항 변화를 유발하는데, 상기의 흡 착 반응은 온도가 낮아질 수록 증가하는 것으로 알려져 있다 ${ }^{18)}$. 따라서, 비교적 낮은 온도에서 센서를 구동하는 것이 산화질소의 고감도, 고선택적 검출에 유리하다. $\mathrm{Kim}$ 등5)은 초음파 분무 열분해(ultrasonic spray pyrolysis)법으로 $\mathrm{WO}_{3}$ 난황구조(yolk-shell spheres) 를 합성한 후, 구동 온도 $\left(100 \sim 300{ }^{\circ} \mathrm{C}\right)$ 에 따른 센서의 산화질소 감도를 측정했다. 그 결과, 구동 온도가 감소할 수록 산화질소 $50 \mathrm{ppb}$ 에 대한 가스감도가 $1.5\left(300{ }^{\circ} \mathrm{C}\right)$ 에서 $100.0\left(100{ }^{\circ} \mathrm{C}\right)$ 까지 급격하게 증가했고, 동시에 방 해 가스(아세톤, 일산화탄소, 암모니아) 대비 산화질소 선택성 또한 크게 증가했다. 이는 실제로 저온에서 센서 를 구동하는 것이 산화질소를 고감도, 고선택적으로 검출 하는데 유리하다는 점을 잘 보여준다. 그러나 온도가 너 무 낮을 경우 센서의 반응 및 회복 속도가 현저하게 저하 되므로, 가스감도, 선택성, 응답속도를 함께 고려해서 센 서의 구동 온도를 최적화하는 것이 매우 중요하다.

Moon 등19)은 스침각 증착법(glancing angle deposition)을 통해 제작한 $\mathrm{WO}_{3}$ villi-like nanofinger 가 $200{ }^{\circ} \mathrm{C}$ 에서 $5 \mathrm{ppm}$ 의 산화질소에 대해 약 275 의 높은 가스감도와 우수한 응답속도를 나타낸다는 결과를 보고 했다 (Fig. 2). 본 센서의 산화질소 검출 한계 (detection limit)는 $88 \mathrm{ppt}$ 로 천식 환자의 호기 산화질소 농도( 30 $\mathrm{ppb})$ 에 비해 충분히 낮았고, 정상인의 호기 에탄올 농도
(0 - $1663 \mathrm{ppb)에} \mathrm{비해} \mathrm{높은} \mathrm{농도의} \mathrm{에탄올}(5 \mathrm{ppm})$ 에도 거의 반응하지 않았다. 이는 상기의 센서가 천식 환자 진 단에 높은 잠재력을 가지고 있다는 점을 시사한다. 이 외 에도 $\mathrm{WO}_{3}$ 기반 센서의 저동 구동을 통해 산화질소에 대 해 우수한 가스감도 및 선택성을 확보하는 연구결과들이 다수 보고되었고 ${ }^{20,21)}, \mathrm{Pd}, \mathrm{Pt}, \mathrm{Au}$ 와 같은 귀금속 촉매를 표면 도포할 경우 가스감도 및 선택성을 더욱 향상시킬 수 있다는 결과가 보고된 바 있다22). 상기의 결과들은 센 서 온도 최적화 및 $\mathrm{WO}_{3}$ 기반 가스센서의 활용이 천식 환 자 진단 용 호기 센서 구현에 매우 유망하다는 점을 잘 보 여준다.

\subsection{2 당뇨병 진단 용 아세톤 센서}

당뇨는 체내의 혈당을 조절하는 호르몬인 인슐린이 모 자라거나, 제대로 기능하지 못해 높은 혈당 상태가 계속 되는 질환을 말한다. 혈당 조절 기능에 이상이 생긴 사람 은 포도당을 제대로 흡수하지 못해 지방을 에너지원으로 사용하게 되며, 이 때 지방분해산물로 아세톤이 생성되어 호기로 배출된다23). 당뇨환자의 호기 아세톤 농도는 $1800 \mathrm{ppb}$ 이상으로 정상인의 $300-900 \mathrm{ppb}$ 에 비해 두 배 이상 높고, 따라서 이를 이용하여 당뇨를 진단할 수 있 다 ${ }^{24)}$. 당뇨환자의 호기 아세톤 농도는 호기 에탄올(0 $1663 \mathrm{ppb}$ )과 유사한데, 대부분의 산화물 반도체형 가스 센서가 아세톤과 에탄올에 거의 유사한 가스감도를 나타 내므로, 두 가스를 구별해 낼 수 있는 감응 소재를 개발하 는 것이 매우 중요하다.

Wang 등)은 아세톤의 에탄올 대비 높은 결합 쌍극자 모멘트(dipole moment)에 착안하여 강유전성 (ferroelectricity)을 갖는 $\varepsilon-\mathrm{WO}_{3}$ 를 가스 감응 소재로 활 용하면, 아세톤을 에탄올 대비 선택적으로 검출할 수 있 다는 연구결과를 발표했다. 일반적으로 상온 이상에서의 $\mathrm{WO}_{3}$ 의 안정상은 강유전성을 나타내지 않는 모노클리닉 (monoclinic) 구조의 $\gamma-\mathrm{WO}_{3}$ 이지만, 상기의 연구에서는 $\mathrm{Cr}$ 과 같은 침입형 도핑재(interstitial dopant)를 첨가하 여 격자의 비대칭성(asymmetry)을 증가시키는 방법으 로 $400^{\circ} \mathrm{C}$ 에서도 안정한 $\varepsilon-\mathrm{WO}_{3}$ 를 합성하는데 성공했다. 화염 분무 열분해(flame spray pyrolysis)법을 통해 합 


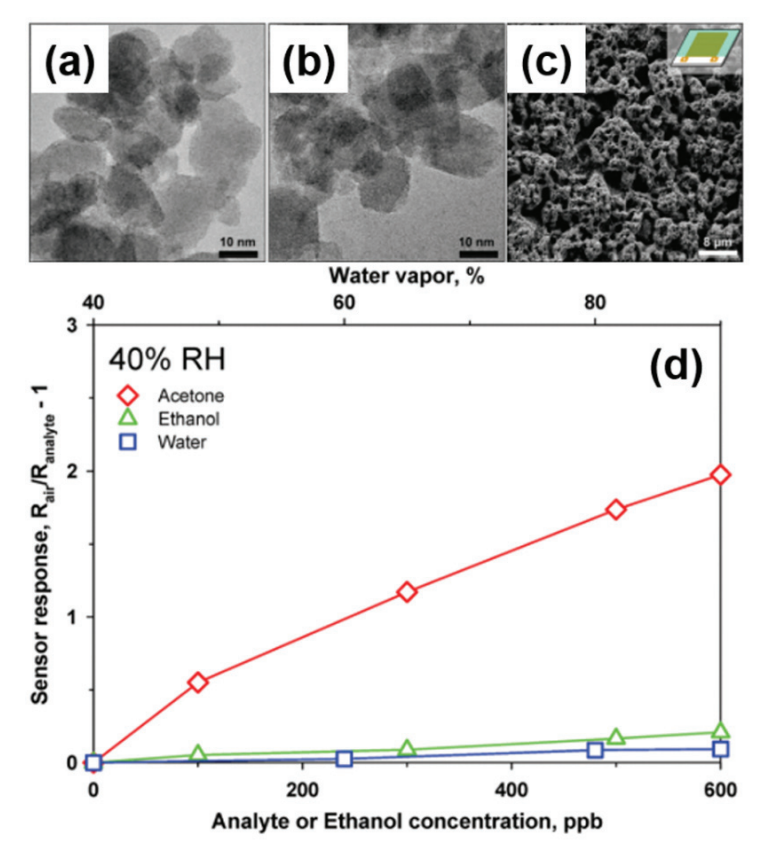

Fig. 3. $(\mathrm{a}-\mathrm{c})$ 화염 분무 열분해법으로 합성한 $\mathrm{Si}$ 이 도핑된 $\mathrm{WO}_{3}$ 나노 입자 $\left(\mathrm{Si}^{\mathrm{W}} \mathrm{WO}_{3}\right),(\mathrm{d}) \mathrm{Si}: \mathrm{WO}_{3}$ 의 가스 감응 특성 ${ }^{7}$.

성된 상기의 $\varepsilon-\mathrm{WO}_{3}$ 나노입자는 $1 \mathrm{ppm}$ 의 아세톤에 대해 약 3 의 가스감도를 나타냈으며, 에탄올 대비 아세톤에 대 해 2배 이상의 선택성을 보였다. 같은 그룹에서 $\mathrm{Si}(10$ $\mathrm{wt} \%)$ 을 침입형 도핑재로 활용하여 합성한 $\varepsilon-\mathrm{WO}_{3}$ 나노 입자는 $400{ }^{\circ} \mathrm{C}$ 에서 $1.8 \mathrm{ppm}$ 의 아세톤에 대해 약 10 의 높 은 가스감도를 보였으며, 같은 농도의 에탄올 대비 4 배 이상의 우수한 아세톤 선택성을 나타냈다) (Fig. 3). 상 기의 센서는 사람의 호기에 대한 PTR-MS와의 교차 검 증을 통해 실제로 호기 아세톤을 매우 정밀하게 분석할 수 있음을 증명했으며 25), 이는 잘 설계된 산화물 반도체 형 가스센서가 호기 분석에 실제로 활용되고 있는 고가 의 $\mathrm{MS}$ 장비들을 충분히 대체할 수 있다는 점을 잘 보여 준다.

최근 Shen 등 ${ }^{26)}$ 은 $\mathrm{Fe}(0.445 \mathrm{at} \%)$ 를 치환형 도핑재 (substitutional dopant)로 활용할 경우에도 $\varepsilon-\mathrm{WO}_{3}$ 를 합성할 수 있다는 점과, 합성된 $\varepsilon-\mathrm{WO}_{3}$ 가 다양한 방해가 스(암모니아, 일산화탄소, 톨루엔, 메탄올, 에탄올, 산화 질소) 대비 아세톤에 높은 선택성을 보인다는 연구결과를 보고했다. 상기의 연구결과들은 $\mathrm{WO}_{3}$ 에 산화물 첨가제를
도핑하여 강유전성을 갖는 $\varepsilon-\mathrm{WO}_{3}$ 를 제조하는 것이 당뇨 환자 진단용 아세톤 센서 개발에 매우 효과적임을 잘 보 여준다. 이외에도 $\mathrm{Pt}^{277}, \mathrm{Rh}^{28)}$ 과 같은 귀금속 촉매를 도포 할 경우 아세톤에 대한 가스 감응 특성을 더욱 향상 시킬 수 있다는 연구결과들이 있으므로, 향 후 관련 연구를 통 해 성능이 더욱 향상된 아세톤 센서가 개발 될 수 있을 것 으로 기대된다.

\subsection{3 신장병 진단 용 암모니아 센서}

만성 신장병(chronic kidney disease)은 3개월 이상 신장이 손상되어 있거나 신장 기능 감소가 지속적으로 나 타나는 상태를 말하는데, 신장의 손상 정도에 따라 $1-5$ 단계로 구분된다. 만성 신장병 환자는 단백질 대사과정에 서 생성된 암모니아가 소변을 통해 정상적으로 배출되지 않아 체내에 축적되었다가 날숨을 통해 배출되므로 정상 인에 비해 높은 호기 암모니아 농도를 보인달). 실제로 만성 신장병 5 기 환자의 호기 암모니아 농도는 820 $14700 \mathrm{ppb}$ 로 정상인(425 - $1800 \mathrm{ppb)에} \mathrm{비해} \mathrm{상당히}$ 높게 나타나며30), 최근에는 그 농도가 각 단계에 비례한 다는 연구결과가 보고되었다 ${ }^{31)}$. 암모니아는 환자의 호기 에 비교적 높은 농도로 존재함에도 정확한 분석이 어려운 데, 그 이유는 대부분의 산화물 반도체형 가스센서에서 낮은 가스감도를 나타내기 때문이다. 따라서 암모니아에 대한 선택성 확보를 위해서는 가스와 감응 소재 간의 반

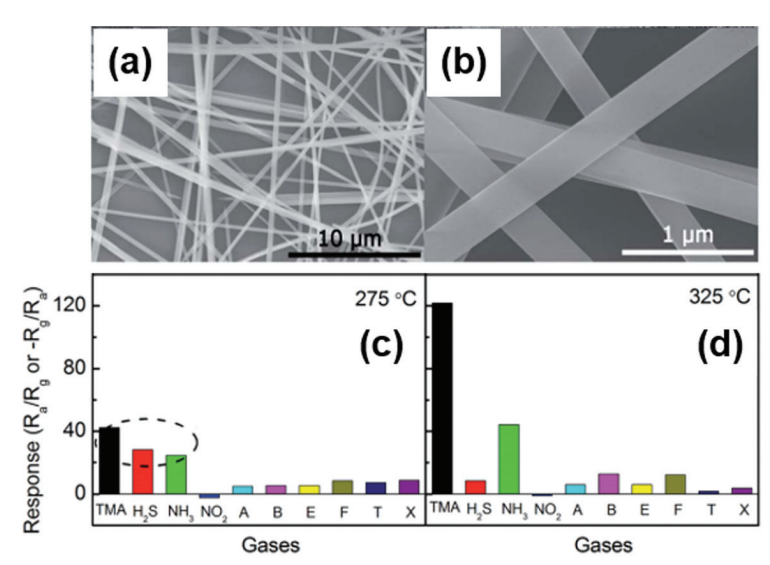

Fig. 4. (a, b) 전기방사법으로 합성한 $\mathrm{MoO}_{3}$ 나노섬유, (c, d) $\mathrm{MoO}_{3}$ 나노섬유의 가스 감응 특성 (TMA: 트리메틸아민, A: 아세톤, $\mathrm{B}$ : 벤젠, $\mathrm{E}:$ 에탄올, $\mathrm{F}$ : 포름알데히드, T: 톨루엔, $\mathrm{X}$ : 자일렌 $)^{9}$. 
응성을 증가시키는 것이 중요하다.

암모니아는 비공유 전자쌍을 가지는 염기성 가스로 산 성 물질에 대해 높은 반응성을 나타내는 것으로 알려져 있다. 따라서 산성 산화물 반도체인 $\mathrm{WO}_{3}$ 나 $\mathrm{MoO}_{3}$ 를 가스 감응 물질로 활용하면 높은 가스감도와 선택성을 확보할 수 있다8,9). Cho 등8)은 초음파 분무 열분해 법을 통해 합 성한 $\mathrm{WO}_{3}$ 중공구조가 $450{ }^{\circ} \mathrm{C}$ 에서 에탄올 대비 암모니아 를 선택적으로 검출할 수 있음을 실험적으로 증명했으며, 상기의 결과는 산성 $\mathrm{WO}_{3}$ 와 염기성 암모니아 사이에서 촉 진된 산-염기 반응에 의한 것으로 이해되었다. $\mathrm{Li}$ 등)은 전기방사(electrospinning) 법을 이용하여 $\mathrm{MoO}_{3}$ 나노섬 유를 합성하고 다양한 가스(암모니아, 트리메틸아민, 황 화수소, 산화질소, 아세톤, 벤젠, 에탄올, 포름알데히드, 톨루엔, 자일렌)에 대한 가스 감응 특성을 평가했는데 (Fig. 4), 그 결과 합성한 $\mathrm{MoO}_{3}$ 나노섬유가 $325{ }^{\circ} \mathrm{C}$ 에서 $5 \mathrm{ppm}$ 의 암모니아에 대해 약 40 이상의 높은 가스감도 와 에탄올 대비 10배 이상의 우수한 암모니아 선택성을 나타낸다는 점을 확인했다. 상기의 연구결과 또한 높은 반응성을 가지는 산 $\left(\mathrm{MoO}_{3}\right)$-염기(암모니아) 반응에 의한 것으로 해석되었으며, 이는 센서가 다른 염기성 가스인 트리메틸아민(TMA)에 대해서도 우수한 가스감응특성을 나타낸다는 점을 통해 뒷받침되었다. 사실, 상기의 센서 는 TMA에 가장 높은 가스감도를 나타냈는데, 이는 TMA 가 암모니아에 비해 분자당 2 개의 비공유 전자쌍을 더 가 지고 있기 때문으로 이해된다. 그러나 건강한 사람의 호 기에서는 TMA가 발견되지 않으므로 ${ }^{22)}$ 호기 분석에서 고 려되어야 하는 주요 방해 가스가 아니며, 오히려 신장병 환자의 호기에서는 미량(1.76 - $38.02 \mathrm{ppb)이} \mathrm{발견된다}$ 는 보고가 있다 ${ }^{32)}$. 이는 산성 산화물 반도체의 활용이 신 장병 진단 용 센서 개발에 다각도로 활용될 수 있다는 점 을 시사한다.

Güntner 등 10)은 $\mathrm{MoO}_{3}$ 에 $3 \mathrm{wt} \%$ 의 $\mathrm{Si}$ 을 도핑하면 순수 한 $\mathrm{MoO}_{3}$ 에 비해 향상된 암모니아 감도와 선택성을 확보할 수 있다는 연구결과를 보고했는데, 이는 암모니아와의 표 면 반응을 더욱 촉진할 수 있는 첨가제의 활용이 암모니아 검출 특성 향상에 유리하다는 점을 시사한다. 염기성 가스 검출에 유망한 첨가제로는 대표적으로 $\mathrm{Cr}_{2} \mathrm{O}_{3}$ 가 있으며
${ }^{33,34)}$, 그 외에도 $\mathrm{Au}$ 와 같은 귀금속 촉매 또한 활용될 수 있 다 ${ }^{35)}$. 따라서 상기의 첨가제 또는 촉매와 산성 산화물 반도 체의 상승효과를 잘 활용하면 호기 암모니아를 정밀하게 측정할 수 있는 센서의 개발이 가능할 것으로 판단된다.

\subsection{4 구취 진단 용 황화수소 센서}

구취란 구강 및 인접 기관에서 발생하여 구강을 통해 외부로 나오는 냄새를 말하며, 일반적으로 구취의 약 $90 \%$ 이상이 휘발성 황 화합물로 구성된다 ${ }^{36)}$. 또한, 휘발 성 황 화합물의 약 $90 \%$ 이상이 황화수소와 메테인 싸이 올로 이루어져 있으므로, 황화수소의 농도를 구취 판단의 객관적 지표로 활용할 수 있다 ${ }^{36)}$. 현재까지 황화수소 형 성의 명확한 병리학적 근거가 규명되지는 않았지만, 실험 적으로 타인에게 불쾌함을 주는 호기 황화수소 농도가 약 $1 \mathrm{ppm}$ 정도로 알려져 있다. 따라서, 호기 황화수소의 측 정을 통해 예방차원의 구취 관리가 가능하다.

현재까지 가장 잘 알려진 황화수소 선택적 검출 방법은 $\mathrm{CuO}$ 를 가스 감응 물질로 활용하거나, 다른 산화물 반도 체 표면에 첨가제로 도포하는 것이다. 그 이유는 반도성 의 $\mathrm{CuO}$ 가 황화수소와 반응하게 되면 전도성의 $\mathrm{CuS}$ 로 변

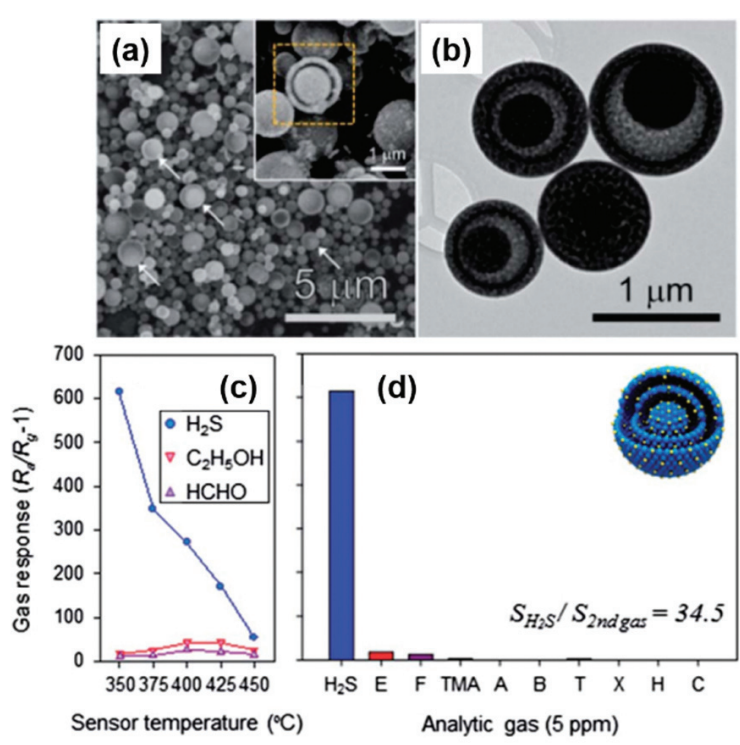

Fig. 5. (a, b) 초음파 분무 열분해 법으로 합성한 $\mathrm{Ag}$ 가 도포된 $\mathrm{SnO}_{2}$ 난황구조 $\left(\mathrm{Ag}-\mathrm{SnO}_{2}-\mathrm{YS}\right),(\mathrm{c}, \mathrm{d}) \mathrm{Ag}-\mathrm{SnO}_{2}-\mathrm{YS}$ 의 가스 감응 특성 (E: 에탄올, $F$ : 포름알데히드, TMA: 트리메틸아민, $A$ : 암모니아, B: 벤젠, T: 톨루엔, X: 자일렌, $\mathrm{H}$ : 수소, C: CO)'11. 
해 높은 저항 변화가 발생하기 때문이다 ${ }^{37} . \mathrm{CuO}$ 를 $\mathrm{n}$ 형 산화물 반도체인 $\mathrm{SnO}_{2}, \mathrm{ZnO}, \mathrm{In}_{2} \mathrm{O}_{3}$ 등의 표면에 도포 할 경우, $\mathrm{CuO}$ 를 가스 감응 소재로 활용했을 때보다 높은 가 스감도 및 선택성을 얻을 수 있는데, 이는 $\mathrm{p}$ 형 산화물 반 도체인 $\mathrm{CuO}$ 와 $\mathrm{n}$ 형 산화물 반도체 사이에 형성된 고저항 의 pn 접합이 $\mathrm{CuS}$ 의 형성으로 인해 급격하게 저저항으 로 변하기 때문이다 ${ }^{12)}$. 실제로 $\mathrm{CuO}$ 가 도포된 $\mathrm{In}_{2} \mathrm{O}_{3}$ 나노 섬유 ${ }^{12)}$ 및 $\mathrm{SnO}_{2}$ 중공구조 ${ }^{13)}$ 의 경우 거의 황화수소에만 선 택적으로 반응한다는 연구결과가 보고되었다.

그러나 $\mathrm{CuO}$ 의 활용은 종종 센서의 느린 회복 특성 또 는 비가역적 동작을 유발하는데, 이는 황화수소와의 반응 으로 형성된 $\mathrm{CuS}$ 가 $\mathrm{CuO}$ 으로 재산화(re-oxidation)되 기 어렵기 때문이다. 이에 황화수소에 대한 가스감도 및 선택성과 함께 센서의 회복 특성 또한 동시에 향상시킬 수 있는 촉매들이 연구되었고, 그 결과 WoO 등38)이 황화 수소에 높은 화학적 친화력을 가지고 있다고 알려진 $\mathrm{Mo}$ 산화물(2.2 $\pm 0.6 \mathrm{at} \%)$ 을 $\mathrm{ZnO}$ 나노선 표면에 도포하는 방법으로 완벽하게 가역적이면서도 우수한 황화수소 감 응 특성을 나타내는 센서를 개발하는데 성공했다. Mo 산 화물 외에도 $\mathrm{Ag}$ 가 황화수소 감응 특성 향상에 효과적인 촉매로 보고되었으며 ${ }^{39)}$, 실제로 $\mathrm{Ag}(0.1 \mathrm{wt} \%)$ 가 도포된 $\mathrm{SnO}_{2}$ 난황구조의 경우 $350{ }^{\circ} \mathrm{C}$ 에서 $1 \mathrm{ppm}$ 의 황화수소에 대해 약 80의 높은 가스감도와 함께 에탄올 대비 30배 이 상의 우수한 선택성 나타냈다1) (Fig. 5). 구취 진단을 위 해 필요한 황화수소 검출 농도가 $1 \mathrm{ppm}$ 정도임을 고려하 면, 상기의 센서는 정밀한 구취 분석에 충분히 활용될 수 있을 것으로 판단된다. 상기의 연구결과들은 $\mathrm{n}$ 형 산화물 반도체 표면에 황화수소와의 친화력이 뛰어난 촉매를 도 포하는 것이 고성능 구취 센서 구현에 효과적이라는 점 과, $\mathrm{Mo}$ 산화물이나 $\mathrm{Ag}$ 가 고감도, 고선택성 및 우수한 가 역성을 나타내는 황화수소 센서 개발에 유용하다는 점을 잘 보여준다.

\subsection{5 폐암 진단 용 탄화수소 센서}

호기 분석을 통한 폐암 진단은 오래전부터 그 시도가 있어 왔지만, 생리학적/병리학적 근거가 아직 명확하지 않고, 실험적으로 어떠한 가스가 생체 지표 가스로 활용
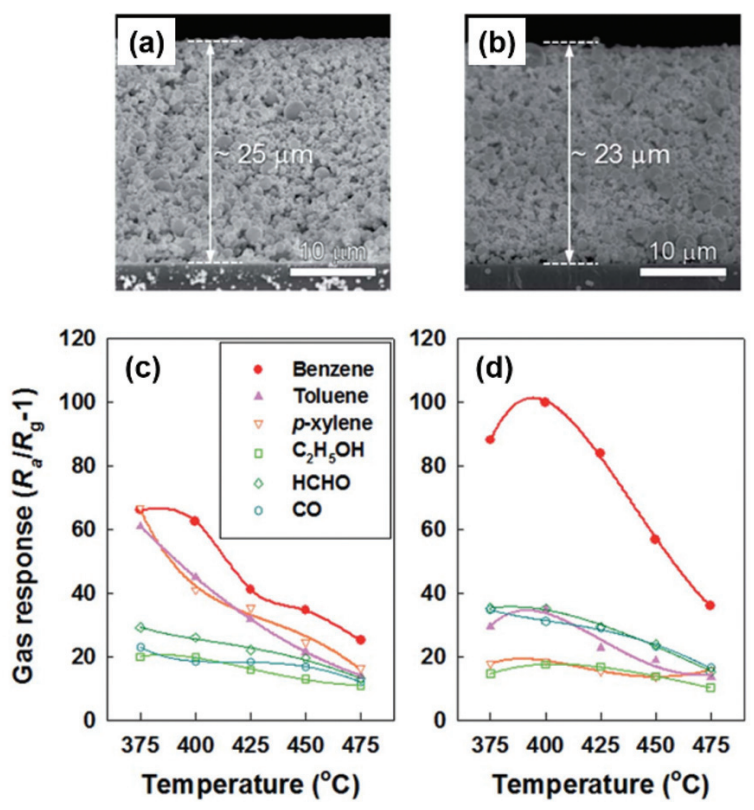

Fig. 6. (a) $\mathrm{Pd}$ 이 도포된 $\mathrm{SnO}_{2}$ 난황구조로 구성된 가스 감응막 $(\mathrm{Pd}-$ $\left.\mathrm{SnO}_{2}\right),(\mathrm{b}) \mathrm{CO}_{3} \mathrm{O}_{4}$ 촉매 층 $(20 \mathrm{~nm})$ 이 Pd- $\mathrm{SnO}_{2}$ 상부에 존 재하는 가스 감응막 $\left(\mathrm{CO}_{3} \mathrm{O}_{4} / \mathrm{Pd}-\mathrm{SnO}_{2}\right),(\mathrm{c}, \mathrm{d}) \mathrm{Pd}-\mathrm{SnO}_{2}$ 와 $\mathrm{Co}_{3} \mathrm{O}_{4} / \mathrm{Pd}-\mathrm{SnO}_{2}$ 의 가스 감응 특성 15 .

될 수 있는가에 대해서도 아직 의견이 분분하다. 현재 약 11 종의 알칸(메탄계 탄화수소) 및 벤젠 계열의 가스(방향 족 탄화수소)들이 유력한 생체 지표 가스 후보군으로 고 려되고 있으며 ${ }^{40)}$, 따라서 호기 분석을 통한 폐암 진단을 위해서는 탄화수소 계열의 가스들을 에탄올 대비 고감도, 고선택적으로 검출할 수 있는 센서의 개발이 필요하다.

그러나 상기의 탄화수소 가스들은 반응성이 우수한 에 탄올에 비해 화학적으로 안정하기 때문에 일반적인 $\mathrm{n}$ 형 산화물 반도체로는 선택적 검출이 매우 어렵다. 반면 $\mathrm{Co}_{3} \mathrm{O}_{4}, \mathrm{Cr}_{2} \mathrm{O}_{3}, \mathrm{NiO}$ 와 같은 $\mathrm{p}$ 형 산화물 반도체는 $\mathrm{n}$ 형 산 화물 반도체에 비해 산소 흡착량이 많아 ${ }^{41}$ 화학적으로 안 정한 가스들을 부분적으로 산화(partial oxidation)시켜 반응성이 우수한 가스 종으로 개질(가스 리포밍 (gas reforming)) 할 수 있으며, 따라서 탄화수소와 같은 안정 한 가스들에 대해 고감도를 얻기에 유리하다 ${ }^{42)}$. 더 구체 적으로 설명하면, 상기의 가스 리포밍은 가스 감응막의 상부에서부터 발생하는데, 리포밍의 결과로 생성된 반응 성이 우수한 가스 종들이 결국 센서의 가스감도에 결정적 
Table 1. 질병 및 생체 지표 가스에 대한 대표적인 고선택성 가스센서7-9,11,14,15,19).

\begin{tabular}{|c|c|c|c|c|c|c|}
\hline Disease & $\begin{array}{l}\text { Biomarker gas } \\
\text { (Conc.) }\end{array}$ & Sensing material & $\begin{array}{c}\text { Gas response (S) } \\
\text { (Conc.) }\end{array}$ & $\begin{array}{c}\text { Selectivity } \\
\left(S_{\text {biomarker gas }} / S_{\text {ethanoo }}\right)\end{array}$ & Sensor temperature & Ref. \\
\hline Asthma & $\begin{array}{c}\mathrm{NO} \\
(30 \mathrm{ppb})\end{array}$ & $\mathrm{WO}_{3}$ & $\begin{array}{c}26 \\
(200 \mathrm{ppb})\end{array}$ & 152 & $200{ }^{\circ} \mathrm{C}$ & 19 \\
\hline Diabetes & $\begin{array}{c}\text { Acetone } \\
1800 \mathrm{ppb})\end{array}$ & $\begin{array}{l}\mathrm{Si} \text {-doped } \mathrm{WO}_{3} \\
\left(\varepsilon-\mathrm{WO}_{3}\right)\end{array}$ & $\begin{array}{c}\sim 10 \\
(1800 \mathrm{ppb})\end{array}$ & $\sim 4$ & $400{ }^{\circ} \mathrm{C}$ & 7 \\
\hline Stage 5 Kidney disease & $\begin{array}{c}\mathrm{NH}_{3} \\
(820-14700 \mathrm{ppb}) \\
\end{array}$ & $\mathrm{MoO}_{3}$ & $\begin{array}{c}\sim 40 \\
(5000 \mathrm{ppb})\end{array}$ & $\sim 10$ & $325^{\circ} \mathrm{C}$ & 9 \\
\hline Chronic kidney disease & $\begin{array}{c}\text { Trimethylamine } \\
(1.76-38.02 \mathrm{ppb})\end{array}$ & $\mathrm{WO}_{3}$ & $\begin{array}{c}\sim 3 \\
(50 \mathrm{ppb})\end{array}$ & 11.8 & $450{ }^{\circ} \mathrm{C}$ & 8 \\
\hline Halitosis & $\begin{array}{c}\mathrm{H}_{2} \mathrm{~S} \\
(\sim 1000 \mathrm{ppb}) \\
\end{array}$ & $\mathrm{Ag}$-loaded $\mathrm{SnO}_{2}$ & $\begin{array}{c}80 \\
(1000 \mathrm{ppb}) \\
\end{array}$ & 34.5 & $350^{\circ} \mathrm{C}$ & 11 \\
\hline \multirow{2}{*}{ Lung cancer } & $\begin{array}{c}\text { Xylene } \\
\text { (n. a.) }\end{array}$ & $\mathrm{Pt}-$ doped $\mathrm{CoCr}_{2} \mathrm{O}_{4}$ & $\begin{array}{c}559 \\
(5000 \mathrm{ppb})\end{array}$ & 87.8 & $275^{\circ} \mathrm{C}$ & 14 \\
\hline & $\begin{array}{l}\text { Benzene } \\
(\mathrm{n} . \mathrm{a} .)\end{array}$ & $\begin{array}{c}\mathrm{Pd} \text {-loaded } \mathrm{SnO}_{2} \\
\text { with } \mathrm{Co}_{3} \mathrm{O}_{4} \text { overlayer }\end{array}$ & $\begin{array}{c}80 \\
(5000 \mathrm{ppb})\end{array}$ & $\sim 4$ & $375^{\circ} \mathrm{C}$ & 15 \\
\hline
\end{tabular}

인 영향을 미치는 전극과 가까운 부분의 가스 감응막과 반응하게 되므로 가스감도가 높게 나타난다. 이 때, 반응 성이 높은 에탄올의 경우 대부분이 가스 감응막의 표면에 서 물이나 이산화탄소와 같은 반응성이 낮은 가스로 산화 (complete oxidation)되며, 따라서 가스감도가 오히려 낮게 나타난다. 이러한 $\mathrm{p}$ 형 산화물 반도체 특유의 가스 리포밍은 반응성이 낮은 가스를 반응성이 높은 가스 대비 선택적으로 검출하는 것을 가능하게 하며, 따라서 에탄올 대비 고선택적 탄화수소 검출 센서 개발에 잠재력이 있다 고 판단된다.

실제로 $\mathrm{p}$ 형 산화물 반도체를 가스 감응 물질로 활용하 여 $n$ 형 산화물 반도체로는 선택적 검출이 어려웠던 방향 족 탄화수소(자일렌, 톨루엔)를 에탄올 대비 고감도, 고 선택적으로 검출하는 연구결과들이 다수 보고되었다 ${ }^{43,44)}$. 특히, $\mathrm{Lee}$ 등 ${ }^{14)}$ 이 발표한 $\mathrm{Pt}$ 이 도핑된 $\mathrm{CoCr}_{2} \mathrm{O}_{4}$ 중 공구조의 경우 $275{ }^{\circ} \mathrm{C}$ 에서 $5 \mathrm{ppm}$ 의 자일렌에 대해 559 의 높은 가스감도와 에탄올 대비 87.8 배의 극히 우수한 자일렌 선택성을 나타냈는데, 이는 실제로 $\mathrm{p}$ 형 산화물 반 도체가 고감도, 고선택적 벤젠 계 탄화수소 검출에 매우 효과적인 가스 감응 소재라는 점을 증명한다.

Jeong 등ㄷ)은 $\mathrm{Pd}$ 이 첨가된 $\mathrm{SnO}_{2}$ 난황구조로 구성된 가스 감응막 $(25 \mu \mathrm{m})$ 의 상부에 가스 리포밍을 촉진할 수 있는 p형 산화물 $\left(\mathrm{Co}_{3} \mathrm{O}_{4}\right)$ 촉매 층 $(20 \mathrm{~nm})$ 을 이빔 증 착(e-beam evaporation)하는 방법으로 이중 층 구조를 가지는 센서를 제작하고, 다양한 가스(벤젠, 톨루엔, 자
일렌, 에탄올, 포름알데히드, 일산화탄소)에 대한 가스 감응 특성을 평가했다(Fig. 6). 그 결과, 센서는 화학적으 로 안정한 벤젠에 대해 $375^{\circ} \mathrm{C}$ 에서 80 이상의 높은 가스 감도와 에탄올 대비 4 배 이상의 우수한 선택성을 나타냈 다. 상기의 결과는 $\mathrm{Co}_{3} \mathrm{O}_{4}$ 촉매 층이 벤젠의 리포밍을 촉 진하는 동시에 그 외의 가스를 완전히 산화 시켰기 때문 으로 이해되었으며, 이는 가스 감응막 표면 촉매 층 형성 을 통한 가스 리포밍 조절이 다양한 종류의 탄화수소 가 스에 대한 선택성 확보에 유망한 방법임을 시사한다.

상기의 연구결과들은 $\mathrm{p}$ 형 산화물 반도체를 가스 감응 소재 또는 촉매로 활용하여 가스 감응막 내 가스 리포밍 을 조절하는 것이 폐암과 밀접한 관계가 있는 탄화수소 계열의 가스들을 선택적으로 검출하는 센서 개발에 잠재 력이 있음을 잘 보여준다.

\section{3 호기 분석 용 전자 코 구현을 위한 고성능 단일 센서 개발의 필요성}

산화물 반도체형 가스센서는 가스 감지 성능의 측면에 서 많은 발전을 이루어왔다. 특히, 가스 선택성은 앞서 언 급한 방법들을 포함하는 다양한 소재 설계 방안들을 통해 에탄올 외에도, 산화질소 ${ }^{19)}$, 아세톤(7), 암모니아9), 트리메 틸아민(8), 황화수소11), 자일렌(4), 벤젠15)의 선택적 검출에 까지 확장되었다. Table 1에 질병 및 생체 지표 가스에 대 한 대표적인 고선택성 가스센서들의 감응 물질, 가스감도 및 에탄올 대비 선택성 등을 요약했다. 


\section{특 집 ㅁㅃ 윤지욱, 이종흔}

이와 같은 센서의 발전에도 불구하고, 현재의 가스센서 어레이 연구는 여전히 에탄올 센서들로 주로 진행되고 있 다. 센서 어레이는 사람의 호기와 같은 복잡한 혼합 가스 를 분석하는데 분명 장점이 있지만, 선택성이 낮은 센서 들로 어레이를 구성하게 되면 그 잠재력을 제대로 활용할 수 없다. Pineau 등45)은 에탄올 $\left(\mathrm{Si}: \mathrm{SnO}_{2}\right)$, 아세톤 $\left(\mathrm{Si}: \mathrm{WO}_{3}\right)$, 암모니아 $\left(\mathrm{Si}: \mathrm{MoO}_{3}\right)$ 센서로 제작한 센서 어레 이(orthogonal sensor array)와 3가지의 $\mathrm{SnO}_{2}$ 기반 에 탄올 센서 $\left(\mathrm{Pd}: \mathrm{SnO}_{2}, \mathrm{Pt}: \mathrm{SnO}_{2}, \mathrm{Si}: \mathrm{SnO}_{2}\right)$ 로 제작한 센서 어레이(collinear sensor array)의 성능을 60 가지 서로 다른 에탄올, 아세톤, 암모니아 혼합 가스 분위기에서 평 가하고 그 결과를 예측 값과 비교하여 단일 센서의 선택 성이 센서 어레이의 성능에 미치는 영향을 고찰했다. 그 결과 orthogonal sensor array의 결정 계수(coefficient of determination, $\mathrm{R}^{2}$ )는 에탄올, 아세톤, 암모니아에 대 해 각각 $0.88,0.99,0.96$ 으로 1 에 가깝게 나타난 반면, collinear sensor array의 경우 각각 $0.28,0.86,0.01$ 로 매우 낮게 나타났다. 특히, 암모니아에 대해서는 $\mathrm{Si}: \mathrm{MoO}_{3}$ 단일 센서 $\left(R^{2}: 0.68\right)$ 만을 활용했을 때보다도 오히려 저하 된 $\mathrm{R}^{2}$ (0.01)을 나타냈는데, 이는 선택성이 부족한 센서 들로 어레이를 구성할 경우 단일 센서에 비해서 오히려 저하된 성능을 나타낼 수도 있다는 점을 시사한다.

상기의 연구결과는 센서 어레이의 잠재력을 극대화 하 기 위해서는 고선택성 가스센서들로 어레이를 구성해야 만 한다는 점을 명확하게 보여준다. 즉, 호기 분석을 통 한 질병 진단 용 전자 코 구현을 위해서는 고감도, 고선택 성 단일 센서들의 개발이 선행되어야 하며, 이를 위해서 는 본 고에서 소개된 방법 및 그 외의 다양한 새로운 전략 들이 요구된다.

\section{3. 결론}

본 고에서는 호기 분석을 통해 천식, 당뇨, 신장병, 구 취 및 폐암을 진단하는데 활용될 수 있는 고성능 생체 지 표 가스(산화질소, 아세톤, 암모니아, 황화수소, 탄화수 소) 검출 센서의 설계 방안을 고찰하고, 호기 분석을 통한 질병 진단 용 전자 코 구현을 위한 고선택적 단일 센서 개
발의 필요성을 강조했다. 호기를 통해 배출되는 생체 지 표 가스는 매우 미량이며, 수백여 종의 가스들과 혼재되 어 있으므로, 이를 검출할 수 있는 고감도, 고선택성 센 서의 개발이 필요하다. 특히, 사람의 날숨에 상대적으로 고농도로 존재하는 에탄올에 높은 가스감도를 나타내는 산화물 반도체형 가스센서의 특성 상 정밀한 호기 분석을 위해서는 극히 우수한 에탄올 대비 생체 지표 가스 선택 성이 요구된다. 상기의 선택성을 확보하는 방법으로는 구 동 온도 최적화(산화질소), 산화물 첨가제 도핑(아세톤), 가스와 감응 소재 간 산-염기 반응 유도(암모니아), 귀금 속 또는 산화물 촉매 도포(황화수소) 및 가스 감응막 내 가스 리포밍 조절(탄화수소) 등의 방법이 있으며, 각 방법 들을 함께 활용하여 상승효과를 유도하면 선택성을 더욱 향상 시킬 수 있다. 센서 어레이는 호기와 같은 혼합 가스 를 분석하는데 유용하지만, 선택성이 낮은 센서들로 어레 이를 구성할 경우 그 잠재력을 제대로 활용하지 못하거 나, 단일 센서에 비해 오히려 저하된 가스 검지 성능을 나 타낼 수도 있다. 따라서 센서 어레이의 잠재력을 극대화 하기 위해서는 고선택성 센서들로 어레이를 구성해야만 한다. 현재 산화질소, 아세톤, 암모니아, 황화수소, 트리 메틸아민, 자일렌, 벤젠과 같은 가스에 우수한 선택성을 나타내는 단일 센서들이 개발되어 있으며, 계속해서 성능 이 향상되고 있다. 따라서, 상기의 센서들을 어레이화하 여 전자 코를 구성할 경우, 단 한 번의 호기 검사로 다양 한 질병을 동시에 진단 할 수 있을 것으로 판단된다. 향후 상기의 전자 코가 스마트폰과 같은 휴대용 전자기기에 통 합되어 일반인들에게 보급되면 개개인이 질병을 자가진 단 할 수 있을 것이며, 이는 궁극적으로 사람들의 삶의 질 을 높이고 생명연장을 실현하는데 핵심적인 기술로 사회 적, 경제적으로 큰 파급효과를 불러올 것으로 예상된다.

\section{참교문헌}

1. L. Pauling, A. B. Robinson, R. Teranish, P. Cary, "Quantitative analysis of urine vapor and breath by gas-liquid partition chromatography" Proc. Nat. Acad. Sci. USA 68 [10] 2374-2376 (1971)

2. M. Righettoni, A. Amann, S. E. Pratsinis, "Breath analysis by nanostructured metal oxides as chemo- 
resistive gas sensors" Mater. Today 18 [3] 163-171 (2015)

3. J.-W. Yoon, J.-H. Lee, "Toward breath analysis on a chip for disease diagnosis using semiconductorbased chemiresistors: recent progress and future perspectives" Lab Chip 17 [21] 3537-3557 (2017)

4. C. Turner, P. Spanel, D. Smith, "A longitudinal study of ethanol and acetaldehyde in the exhaled breath of healthy volunteers using selected-ion flow-tube mass spectrometry" Rapid Commun. Mass Spectrom. 20 [1] 61-68 (2006)

5. J.-S. Kim, J.-W. Yoon, Y. J. Hong, Y. C. Kang, F. Abdel-Hady, A. A. Wazzan, J.-H. Lee, "Highly sensitive and selective detection of ppb-level $\mathrm{NO}_{2}$ using multi-shelled $\mathrm{WO}_{3}$ yolk-shell spheres" Sens. Actuators B 229 561-569 (2016)

6. L. Wang, A. Teleki, S. E. Pratsinis, P. I. Gouma, "Ferroelectric $\mathrm{WO}_{3}$ nanoparticles for acetone selective detection" Chem. Mater. 20 [15] 4794-4796 (2008)

7. M. Righettoni, A. Tricoli, S. E. Pratsinis, "Si: $\mathrm{WO}_{3}$ sensors for highly selective detection of acetone for easy diagnosis of diabetes by breath analysis" Anal. Chem. 82 [9] 3581-3587 (2010)

8. Y. H. Cho, Y. C. Kang, J.-H. Lee, "Highly selective and sensitive detection of trimethylamine using $\mathrm{WO}_{3}$ hollow spheres prepared by ultrasonic spray pyrolysis" Sens. Actuators B 176 971-977 (2013)

9. H.-Y. Li, L. Huang, X.-X. Wang, C.-S. Lee, J.-W. Yoon, J. Zhou, X. Guo, J.-H. Lee, "Molybdenum trioxide nanopaper as a dual gas sensor for detecting trimethylamine and hydrogen sulfide" $R S C A d v .7$ [7] 3680-3685 (2017).

10. A. T. Güntner, M. Righettoni, S. E. Pratsinis, "Selective sensing of $\mathrm{NH}_{3}$ by $\mathrm{Si}$-doped $\alpha-\mathrm{MoO}_{3}$ for breath analysis" Sens. Actuators B 223 266-273 (2016)

11. J.-W. Yoon, Y. J. Hong, Y. C. Kang, J.-H. Lee, "High performance chemiresistive $\mathrm{H}_{2} \mathrm{~S}$ sensors using $\mathrm{Ag}$-loaded $\mathrm{SnO}_{2}$ yolk-shell nanostructures" RSC Adv. 4 [31] 16067-16074 (2014)

12. X. Liang, T.-H. Kim, J.-W. Yoon, C.-H. Kwak, J. -H. Lee, "Ultrasensitive and ultraselective detection of $\mathrm{H}_{2} \mathrm{~S}$ using electrospun $\mathrm{CuO}$-loaded $\mathrm{In}_{2} \mathrm{O}_{3}$ nanofiber sensors assisted by pulse heating" Sens. Actuators $B$ 209 934-943 (2015)

13. K.-I. Choi, H.-J. Kim, Y. C. Kang, J.-H. Lee, "Ultraselective and ultrasensitive detection of $\mathrm{H}_{2} \mathrm{~S}$ in highly humid atmosphere using $\mathrm{CuO}-$ loaded $\mathrm{SnO}_{2}$ hollow spheres for real-time diagnosis of halitosis" Sens. Actuators B 194 371-376 (2014)

14. K. H. Lee, B.-Y. Kim, J.-W. Yoon, J.-H. Lee, "Extremely selective detection of ppb levels of indoor xylene using $\mathrm{CoCr}_{2} \mathrm{O}_{4}$ hollow spheres activated by $\mathrm{Pt}$ doping" Chem. Commun. 55 [6] 751-754 (2019)

15. S. -Y. Jeong, J. -W. Yoon, T. - H. Kim, H. -M. Jeong, C.-S. Lee, Y. C. Kang, J.-H. Lee, "Ultra-selective detection of sub-ppm-level benzene using $\mathrm{Pd}-\mathrm{SnO}_{2}$ yolk-shell micro-reactors with a catalytic $\mathrm{Co}_{3} \mathrm{O}_{4}$ overlayer for monitoring air quality" J. Mater. Chem. A 5 [4] 1446-1454 (2017)

16. S. -H. Kim, H.-J. Yoon, "Use of the exhaled nitric oxide for management of asthma and respiratory disease" Korean J. Med. 74 [6] 579-586 (2008)

17. S. A. Kharitonov, F. Gonio, C. Kelly, S. Meah, P. J. Barnes, "Reproducibility of exhaled nitric oxide measurements in healthy and asthmatic adults and children" Eur. Respir. J. 21 [3] 433-438 (2003)

18. M. Machida, M. Uto, D. Kurogi, T. Kijima, ${ }^{M n O}{ }_{x}-$ $\mathrm{CeO}_{2}$ binary oxides for catalytic $\mathrm{NO}_{\mathrm{x}}$ sorption at low temperatures. Sorptive removal of $\mathrm{NO}_{\mathrm{x}}$ " Chem. Mater. 12 [10] 3158-3164 (2000)

19. H. G. Moon, Y. R. Choi, Y.-S. Shim, K.-I. Choi, J.-H. Lee, J.-S. Kim, S.-J. Yoon, H.-H. Park, C.-Y. Kang, H. W. Jang, "Extremely sensitive and selective $\mathrm{NO}$ probe based on villi-like $\mathrm{WO}_{3}$ nanostructures for application to exhaled breath analyzers" ACS Appl. Mater. Interface 5 [21] 1059110596 (2013)

20. W.-T. Koo, S.-J. Choi, N.-H. Kim, J.-S. Jang, I.-D. Kim, "Catalyst-decorated hollow $\mathrm{WO}_{3}$ nanotubes using layer-by-layer self-assembly on polymeric nanofiber templates and their application in exhaled breath sensor" Sens. Actuators B 223 301310 (2016)

21. C.-Y. Lee, S.-J. Kim, I.-S. Hwang, J.-H. Lee, "Glucose-mediated hydrothermal synthesis and gas sensing characteristics of $\mathrm{WO}_{3}$ hollow microspheres" Sens. Actuators B 142 [1] 236-242 (2009)

22. M. Penza, C. Martucci, G. Cassano, " $\mathrm{NO}_{\mathrm{x}}$ gas sensing characteristics of $\mathrm{WO}_{3}$ thin films activated by noble metals (Pd, Pt, Au) layers" Sens. Actuators B 50 [1] 52-59 (1998)

23. O. E. Owen, V. E. Trapp, C. L. Skutches, M. A. Mozzoli, R. D. Hoeldtke, G. Boden, G. A. Reichard, "Acetone metabolism during diabetic ketoacidosis" Diabetes 31 [3] 242-248 (1982) 
24. C. Deng, J. Zhang, X. Yu, W. Zhang, X. Zhang, "Determination of acetone in human breath by gas chromatography-mass spectrometry and solidphase microextraction with on-fiber derivatization" J. Chromatogr. B 810 [2] 269-275 (2004)

25. A. T. Güntner, N. A. Sievi, S. J. Theodore, T. Gulich, M. Kohler, S. E. Pratsinis, "Noninvasive body fat burn monitoring from exhaled acetone with $\mathrm{Si}$-doped $\mathrm{WO}_{3}$-sensing nanoparticles" Anal. Chem. 89 [19] 10578-10584 (2017)

26. J.-Y. Shen, M.-D. Wang, Y.-F. Wang, J.-Y. Hu, Y. Zhu, Y. X. Zhang, Z.-J. Li, H.-C. Yao, "Iron and carbon codoped $\mathrm{WO}_{3}$ with hierarchical walnut-like microstructure for highly sensitive and selective acetone sensor" Sens. Actuators B 256 27-37 (2018)

27. S. -J. Choi, I. Lee, B.-H. Jang, D. -Y. Youn, W.-H. Ryu, C. O. Park, I.-D. Kim, "Selective diagnosis of diabetes using Pt-functionalized $\mathrm{WO}_{3}$ hemitube networks as a sensing layer of acetone in exhaled breath" Anal. Chem. 85 [3] 1792-1796 (2013)

28. N.-H. Kim, S.-J. Choi, S.-J. Kim, H.-J. Cho, J.-S. Jang, W.-T. Koo, M. Kim, I. -D. Kim, "Highly sensitive and selective acetone sensing performance of $\mathrm{WO}_{3}$ nanofibers functionalized by $\mathrm{Rh}_{2} \mathrm{O}_{3}$ nanoparticles" Sens. Actuators B 224 185-192 (2016)

29. S. T. Krishnan, J. P. Devadhasan, S. Kim, "Recent analytical approaches to detect exhaled breath ammonia with special reference to renal patients" Anal. Bioanal. Chem. 409 [1] 21-31 (2017)

30. S. Davies, P. Spanel, D. Smith, "Quantitative analysis of ammonia on the breath of patients in end-stage renal failure" Kidney Int. 52 [1] 223-228 (1997)

31. J. Obermeier, P. Trefz, J. Happ, J. K. Schubert, H. Staude, D. -C. Fischer, W. Miekisch, "Exhaled volatile substances mirror clinical conditions in pediatric chronic kidney disease" PLoS ONE 12 [6] e0178745 (2017)

32. Grabowska-Polanowska, J. Faber, M. Skowron, P. Miarka, A. Pietrzycka, I. Sliwka, A. Amann, "Detection of potential chronic kidney disease markers in breath using gas chromatography with massspectral detection coupled with thermal desorption method" J. Chromatogr. A 1301 [2] 179-189 (2013)

33. H. -S. Woo, C. W. Na, I. -D. Kim, J.-H. Lee, "Highly sensitive and selective trimethylamine sensor using one-dimensional $\mathrm{ZnO}-\mathrm{Cr}_{2} \mathrm{O}_{3}$ hetero-nanostructures" Nanotechnology 23 [24] 245501 (2012)

34. C.-H. Kwak, H.-S. Woo, J.-H. Lee, "Selective trimethylamine sensors using $\mathrm{Cr}_{2} \mathrm{O}_{3}$-decorated $\mathrm{SnO}_{2}$ nanowires" Sens. Actuators B 204 231-238 (2014)

35. T.-H. Kim, J.-W. Yoon, Y. C. Kang, F. AbdelHady, A. A. Wazzan, J.-H. Lee, "A strategy for ultrasensitive and selective detection of methylamine using $\mathrm{p}$-type $\mathrm{Cr}_{2} \mathrm{O}_{3}$ : Morphological design of sensing materials, control of charge carrier concentrations, and configurational tuning of Au catalysts" Sens. Actuators B 240 1049-1057 (2017)

36. S.-J. Lee, S.-T. Kim, H.-S. Kim, "A study on the measurement of halitosis of human mouth with chemical gas sensor arrays" J. Sens. Sci. Technol, 20 [4] 279-285 (2011)

37. J. Chen, K. Wang, L. Hartmann, W. Zhou, "H2S detection by vertically aligned $\mathrm{CuO}$ nanowire array sensors" J. Phys. Chem. C112 [41] 16017-16021 (2008)

38. H.-S. Woo, C.-H. Kwak, I.-D. Kim, J.-H. Lee, "Selective, sensitive, and reversible detection of $\mathrm{H}_{2} \mathrm{~S}$ using $\mathrm{Mo}-$ doped $\mathrm{ZnO}$ nanowire network sensors" $J$. Mater. Chem. A 2 [18] 6412-6418 (2014)

39. Y. Wang, Y. Wang, J. Cao, F. Kong, H. Xia, J. Zhang, B. Zhu, S. Wang, S. Wu, "Low-temperature $\mathrm{H}_{2} \mathrm{~S}$ sensors based on $\mathrm{Ag}$-doped $\alpha-\mathrm{Fe}_{2} \mathrm{O}_{3}$ nanoparticles" Sens. Actuators B 131 [1] 183-189 (2008)

40. X. Chen, M. Cao, Y. Li, W. Hu, P. Wang, K. Ying, H. Pan, "A study of an electronic nose for detection of lung cancer based on a virtual SAW gas sensors array and imaging recognition method" Meas. Sci. Technol. 16 [8] 1535-1546.

41. M. Iwamoto, Y. Yoda, N. Yamazoe, T. Seiyama, "Study of metal oxide catalysts by temperature programmed desorption. 4. Oxygen adsoption on various metal oxides" J. Phys. Chem. 82 [24] 25642570 (1978)

42. H. -J. Kim, J. -H. Lee, "Highly sensitive and selective gas sensors using $\mathrm{p}$-type oxide semiconductors: Overview" Sens. Actuators B 192 607-627 (2014)

43. J. -W. Yoon, Y. J. Hong, G. D. Park, S.-J. Hwang, F. Abdel-Hady, A. A. Wazzan, Y. C. Kang, J.-H. Lee, "Kilogram-scale synthesis of $\mathrm{Pd}$-loaded quintuple-shelled $\mathrm{Co}_{3} \mathrm{O}_{4}$ microreactors and their application to ultrasensitive and ultraselective detection of methylbenzenes" ACS Appl. Mater. Interfaces 7 [14] 7717-7723 (2015)

44. S. -J. Hwang, K.-I. Choi, J.-W. Yoon, Y. C. Kang, J.-H. Lee, "Pure and palladium-loaded $\mathrm{Co}_{3} \mathrm{O}_{4}$ hollow hierarchical nanostructures with giant and 
ultraselective chemiresistivity to xylene and toluene" Chem. Eur. -J. 21 [15] 5872-5878 (2015)

45. N. J. Pineau, J. F. Kompalla, A. T. Güntner, S. E.
Pratsinis, "Orthogonal gas sensor arrays by chemoresistive material design" Microchim. Acta 185 563 (2018)

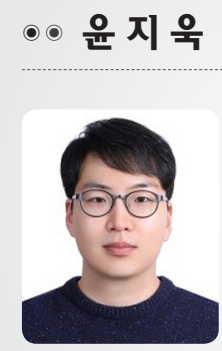

○ 2011년 고려대학교 학사

○ 2017년 고려대학교 박사

○ 2018년 (스위스) 취리히 연방공과대학교 박사후연구원

() 2019년 고려대학교 연구교수

○ 2019년 전북대학교 조교수

\section{ㅇㅇㅇㅣ 종 흔}

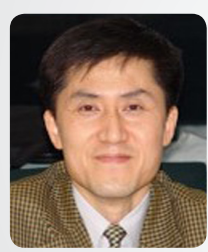

( 1987 년 서울대학교 학사

○ 1989년 서울대학교 석사

○ 1993년 서울대학교 박사

- 1999년 삼성종합기술원 책임연구원

○ 2000년 (일본) 재료연구기구 STA fellow

- 2003년 서울대학교 연구교수

- 2003년 고려대학교 부교수, 정교수 